\title{
Propagation Models for GSM 900 and 1800 MHz for Port Harcourt and Enugu, Nigeria
}

\author{
Julie C. Ogbulezie ${ }^{1}$, M. U. Onuu ${ }^{1}$, J. O. Ushie ${ }^{1} \&$ B. E. Usibe ${ }^{1}$ \\ ${ }^{1}$ Department of Physics, University of Calabar, Nigeria \\ Correspondence: Julie C. Ogbulezie, Department of Physics, University of Calabar, Nigeria. E-mail: \\ jlezie@yahoo.com
}

Received: March 13, 2013 Accepted: June 7, 2013 Online Published: June 30, 2013

doi:10.5539/nct.v2n2p1 URL: http://dx.doi.org/10.5539/nct.v2n2p1

\begin{abstract}
For the cellular networks to effectively cover a terrain or environment, accurate prediction of the coverage of the radio frequency signal is highly needed. Wave propagation models are essential and very important tools for determining the wave propagation characteristics for a particular environment. Path loss predictions are therefore required for the coverage planning, determination of multipath effects as well as interference and cell calculations. These calculations lead to high level network planning. Drive test measurements were taken along certain routes in Port Harcourt and Enugu, cities in Nigeria. These measurements were compared with calculated values from Okumura- Hata and COST231 Hata models. The average path loss values for the routes ranged from $135.01 \mathrm{db}$ to $138.48 \mathrm{db}$ at $900 \mathrm{MHz}, 142.26 \mathrm{db}$ to $147.30 \mathrm{db}$ at $1800 \mathrm{MHz}$. The standard deviations varied from $2.71 \mathrm{db}$ to $15.94 \mathrm{db}$ for the Okumura Hata model at $900 \mathrm{MHz}$ whereas for the COST231 Hata model it was from $1.91 \mathrm{db}$ to $15.04 \mathrm{db}$. Similarly, the mean square errors $\left(\mu_{\mathrm{e}}\right)$ ranged from $0.8 \mathrm{db}$ to $5.04 \mathrm{db}$ for Okumura Hata at $900 \mathrm{MHz}$. For COST 231 Hata at this frequency, it was from $0.6 \mathrm{db}$ to $4.76 \mathrm{db}$. This agrees with the acceptable International range. The acceptable range lies between $1 \leq \mu \leq 15 \mathrm{db}$ (Wu \& Yuan, 1998). The mean square error at $1800 \mathrm{MHz}$ varied from $0.11 \mathrm{db}$ to $5.40 \mathrm{db}$.
\end{abstract}

Keywords: path loss, Okumura-Hata model, COST231 Hata model

\section{Introduction}

GSM networks in Nigeria have been plagued by customer dissatisfaction as a result of poor coverage. Poor coverage brings about frequent drop calls, poor quality of service, poor interconnectivity, echoes and general congestion. The need to therefore investigate the causes of these in detail brought about the actual measurements of signals in Port Harcourt and Enugu cities in Nigeria. Standard empirical path loss models that do not take into consideration the unique geological and terrain of these cities are used by the operators in Nigeria. The research work is aimed at:

(a) Determining adaptable and suitable propagation path loss models for the cities of Port Harcourt and Enugu using the Okumura-Hata and COST 231 Hata models by considering two selected sites for each city.

(b) Investigating the variation in path loss between the measured and predicted values according to these models.

(c) Finding the missing experimental data using interpolation method.

(d) Modifying the standard model to suit these cities according to results obtained through the investigations.

\subsection{Literature Review}

For a cellular network operated to have a network with optimal coverage and is effective, then appropriate prediction of the radio frequency signal is a necessity. Transmission losses, environmental losses, shadowing as power margins to account for multipath fading are parameters taken into consideration before a particular path loss model is accepted.

Tamir (1977) and Cavalcante et al. (1983) have extensively studied the behaviour of propagating electromagnetic waves through forests and tick woods. Some calibration processes to be used in modifying the model parameters to accurately approximate the relevant measured data were proposed by Parsons (2000). This 
work was an extension of the work earlier done by Crane (1980). Abhayawardhana et al. (2003) did a comprehensive set of propagation measurements at $3.5 \mathrm{GHz}$ in Cambridge, United Kingdom. They compared three methods namely COST 231 Hata model, Stanford University interim (SUI) and ECC-33 models.

The effects of rainfall rates on propagation along line-of-sight (LOS) for wireless access paths were investigated by Georgiadou et al. (2006). Their findings reveal that higher rainfall rates lead to higher distortion of signals and therefore larger paths of propagation.

Naldongar (2007) carried out an assessment of the impact of Harmmattan particularly on microwave propagation in the savannah region of West Africa. He concluded that different forms of precipitation, dust etc lead to attenuation of signal significantly.

Nadir, Elfadhil and Touati (2008) determined the path loss using Okumura-Hata for Oman. His study was carried out in the urban areas of Oman using measurements from Oman mobile.

\subsection{Some Standard Path Loss Models}

\subsubsection{Okumura - Hata Model}

This is the commonly employed model for urban and sub-urban areas. This model is the most commonly used for macro-cell coverage planning. This is a combination of the work of Okumura and Hata. Okumura was able to carry out test measurements in Japan. These measurements had a range of clutter type, transmitter height, transmitter power and frequency. He found out that the signal strength decreases at a much greater rate with distance than the predicted free space loss (Medeisis \& Kajackas, 2000; Saunders \& Hata, 1980; Wilson \& Scholtz, 2003).

Hata based his model on Okumura's free test results and predicted various equations for path loss with different types of clutter. The range of tests was carried out from carrier frequency, $150 \mathrm{MHz}$ to $1500 \mathrm{MHz}$. The distance from the base station ranges from $1 \mathrm{~km}$ to $20 \mathrm{~km}$ while the range of the height of the mobile antenna is from $1 \mathrm{~m}$ to $10 \mathrm{~m}$.

The path loss in $\mathrm{db}$ for the urban environment is given by Rappaport (2003)

$$
L_{p}(\text { urban })(d B)=A+B \log (d)
$$

where $\mathrm{d}=$ distance in kilometre.

$\mathrm{A}=$ is a fixed loss that depends on the frequency of the signal. A is given by

$$
\begin{gathered}
A=69.55+26.16 \log _{10}(f)-13.82 \log _{10}\left(h_{b}\right)-a\left(h_{m}\right) \quad \text { and } \\
B=44.9-6.55 \log _{10}\left(h_{b}\right)
\end{gathered}
$$

where $f$ is frequency measured in $\mathrm{MHz}$;

$\mathrm{h}_{\mathrm{b}}=$ height of the base station antenna in metres;

$\mathrm{h}_{\mathrm{m}}=$ height of mobile antenna in metres;

$a\left(\mathrm{~h}_{\mathrm{m}}\right)=$ correction factor in $\mathrm{dB}$.

Therefore

$$
\begin{gathered}
L_{p}(\text { urban })=69.55+26.16 \log _{10}(f)-13.82 \log _{10}\left(h_{b}\right)-a\left(h_{m}\right)+\left[44.9-6.55 \log _{10}\left(h_{b}\right)\right] \log _{10}(d) \\
a\left(h_{m}\right)=\left[1.1 \log _{10}(f)-0.7\right] h_{m}-\left[1.56 \log _{10}(f)-0.8\right]
\end{gathered}
$$

Okumura - Hata model is not suitable for micro-cell planning where antenna is below roof height. It is not valid for $1800 \mathrm{MHz}$ and $1900 \mathrm{MHz}$ systems.

\subsubsection{COST 231 Hata Model}

COST is an acronym for European Co-operative for Scientific and Technical research. COST 231 Hata is an extension of the Okumura - Hata model. The COST 231 Hata model and is designed to be used in the frequency range $500 \mathrm{MHz}$ to $2000 \mathrm{MHz}$. It has correction for urban, suburban and rural (flat) environments. Because of its simplicity and correction factors, it is widely used for path loss predictions at these frequency bands (COST, 1999; Hata, 1981; Okumura, 1968; Wong \& Teng, 1997; Wu \& Yuan, 1998). 
The path loss in urban area is given by

$$
P_{L}(d B)=[46.33+33.9 \log (f)]-\left[13.82 \log \left(h_{b}\right)\right]-a h_{m}+\left[44.9-6.55 \log \left(h_{b}\right)\right] \log (d)
$$

where

$$
a\left(h_{m}\right)=1.1 \log (f)-0.7 h_{m}-1.56 \log (f)-0.8
$$

$\mathrm{h}_{\mathrm{b}}=$ height of base station antenna in meters;

$\mathrm{h}_{\mathrm{m}}=$ height of mobile antenna in meters;

$a\left(\mathrm{~h}_{\mathrm{m}}\right)=$ correction factor in $\mathrm{dB}$.

\section{Materials and Method}

The materials used for these investigations included Eriksson Test Mobile System (TEMS) investigation software, handset complete with charger and other accessories and a laptop. GSM signals operating on the frequencies of $900 \mathrm{MHz}$ and $1800 \mathrm{MHz}$ were under investigation in this research. These are the two frequencies used by mobile operators in Nigeria. The measurement data were obtained by conducting drive tests on the sites under study. The path loss measurements on both GSM bands were obtained through these drive tests conducted alone two routes selected in each city. The two routes were selected based on their uniqueness in order to represent the features of these cities. That is, the sites were selected to represent the most common propagation characteristics of the area under study.

The TEMS mobile phone was used to indicate the calls during the data collection stage. The data was collected starting from a distance of $0.5 \mathrm{~km}$ from the selected base station. The vehicle was moved along the selected routes from the site up to a distance of five kilometres. Obstruction and terrain were observed. The process was respected for each sector of the site under consideration.

The measurements were performed in a car and speed limit kept as constant as possible on weekends to avoid traffic issues and errors. The measurements were carried out in June for a period of two days in each city for accuracy. The equipment for the drive test was placed in a vehicle maintained at an average speed of $30 \mathrm{~km} / \mathrm{h}$. In all the readings mobile antennas height was 1.5 .

The study involved obtaining the mean path loss values at $900 \mathrm{MHz}$ and $1800 \mathrm{MHz}$ at specific receiver distances along the routes chosen. Different values were obtained at different receiver distances for each sector of the respective test stations. The mean values were calculated. These values represented the field measurement values. These measured values were then compared with those calculated from standard Okumura-Hata and CoST-231 Hata models.

These values from the calculated Okumura-Hata and COST-231 Hata models were compared with the measured values. The various standard deviations were calculated from the equation.

$$
\sigma=\sqrt{\sum \frac{\left(P_{m}-P_{r}\right)^{2}}{N}}
$$

The mean square error $\left(\mu_{\mathrm{e}}\right)$ is also given by

$$
\mu_{e}=\frac{\sigma}{\sqrt{N}}
$$

Tables 1 and 2 show the measured path loss values for the two sites in each city. The mean square errors $\mu_{\mathrm{e}}$ for each site was subtracted from the equations of the Okumura - Hata and COST 231 Hata models for that particular site to give the proposed model equations for the sites. The values for the standard deviations and mean square errors are found in Tables 3 and 4 . These proposed equations were written out in the format specified in Equation (1) and tabulated in Tables 3 and 4.

\section{Results and discussion}

Figures $1 \mathrm{a}$ to $4 \mathrm{~b}$ show the graphical representations of the theoretical and measured values of the two sites for each city under consideration at the two frequencies. The sites considered in Enugu are found in Agbani and Ogui Road while that of Port Harcourt are Mile One and Rumuolumeni. Figure 5 gives a plot of the proposed equations for Enugu found in Table 1. Similar plots can be obtained at $1800 \mathrm{MHz}$ for Enugu and also for Port Harcourt for the two frequencies using Tables 3 and 4. 


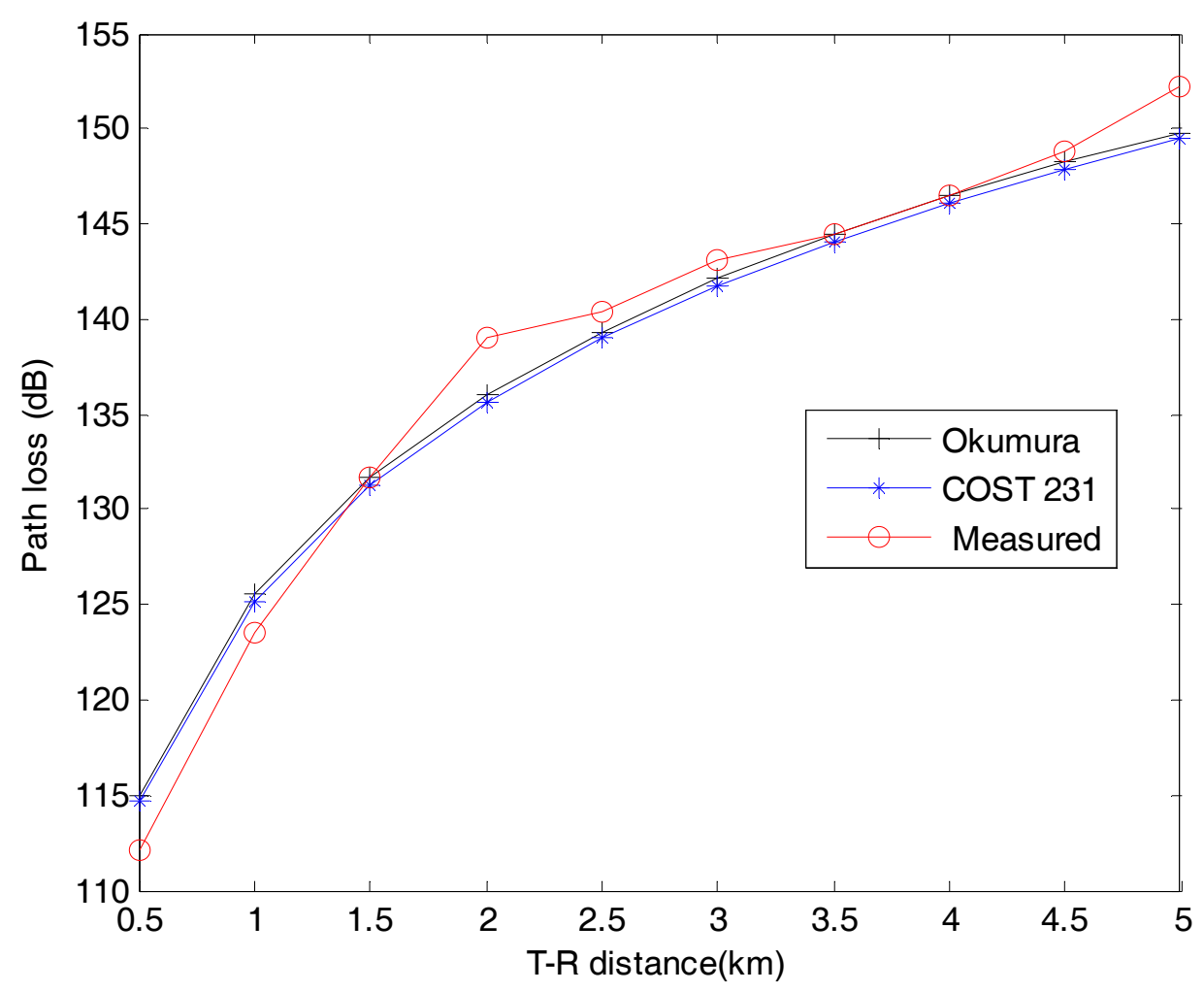

Figure 1a. Path loss at $900 \mathrm{MHz}$ for classic models and measured for Agbani Rd

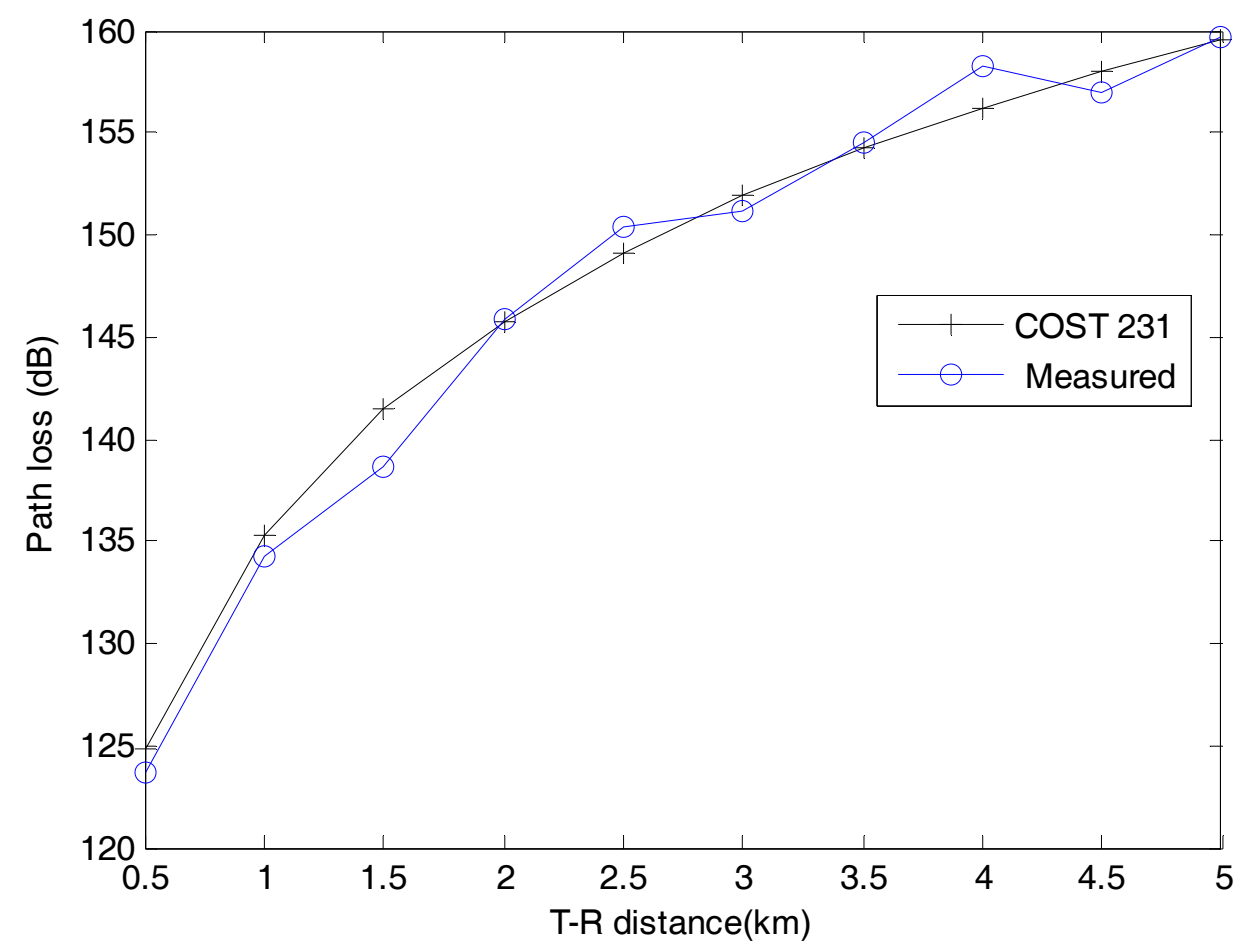

Figure 1b. Path losss at $1800 \mathrm{MHz}$ for COST231 model and measured for Agbani 


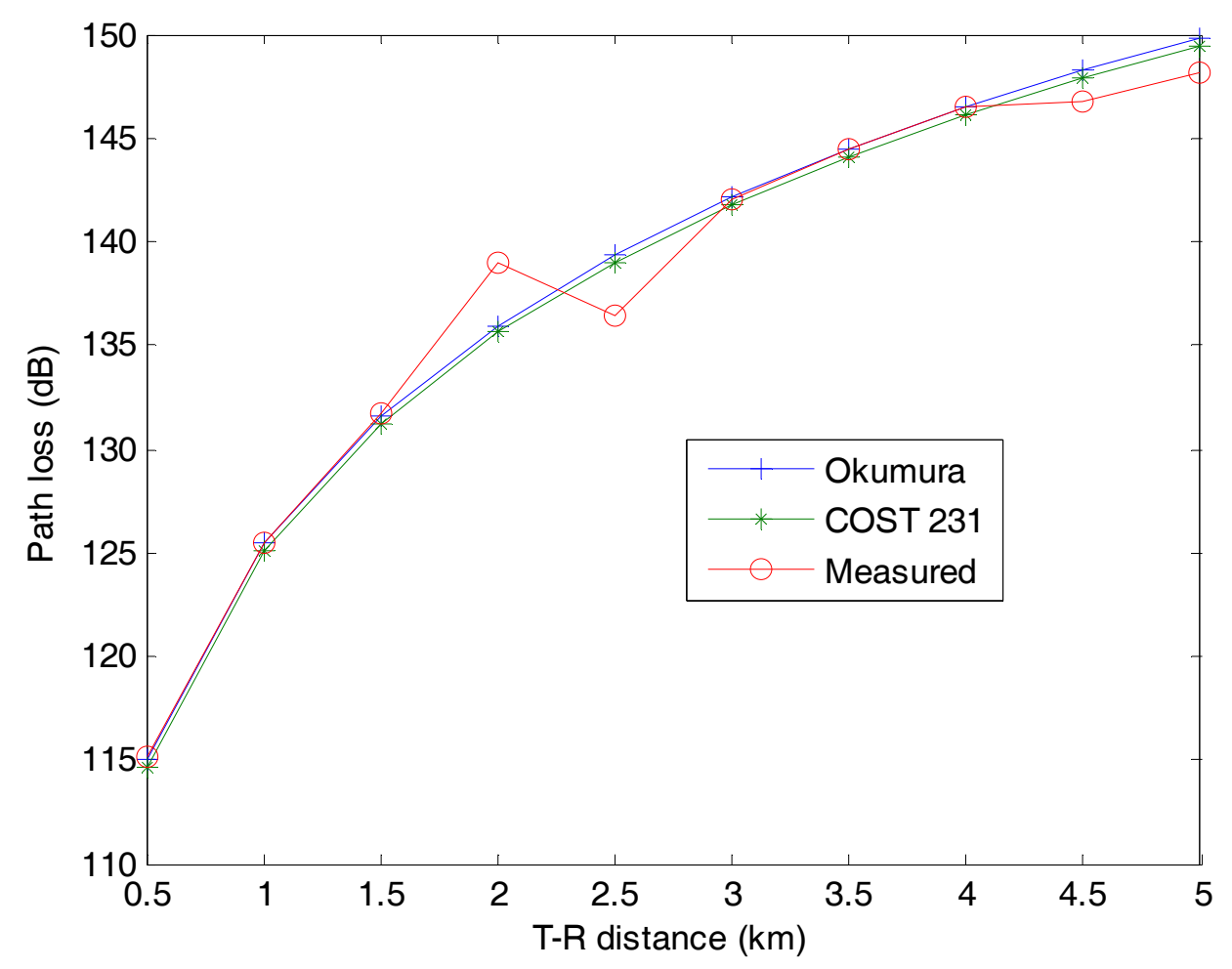

Figure 2a. Path loss at $900 \mathrm{MHz}$ for classic models and measured for Ogui Rd

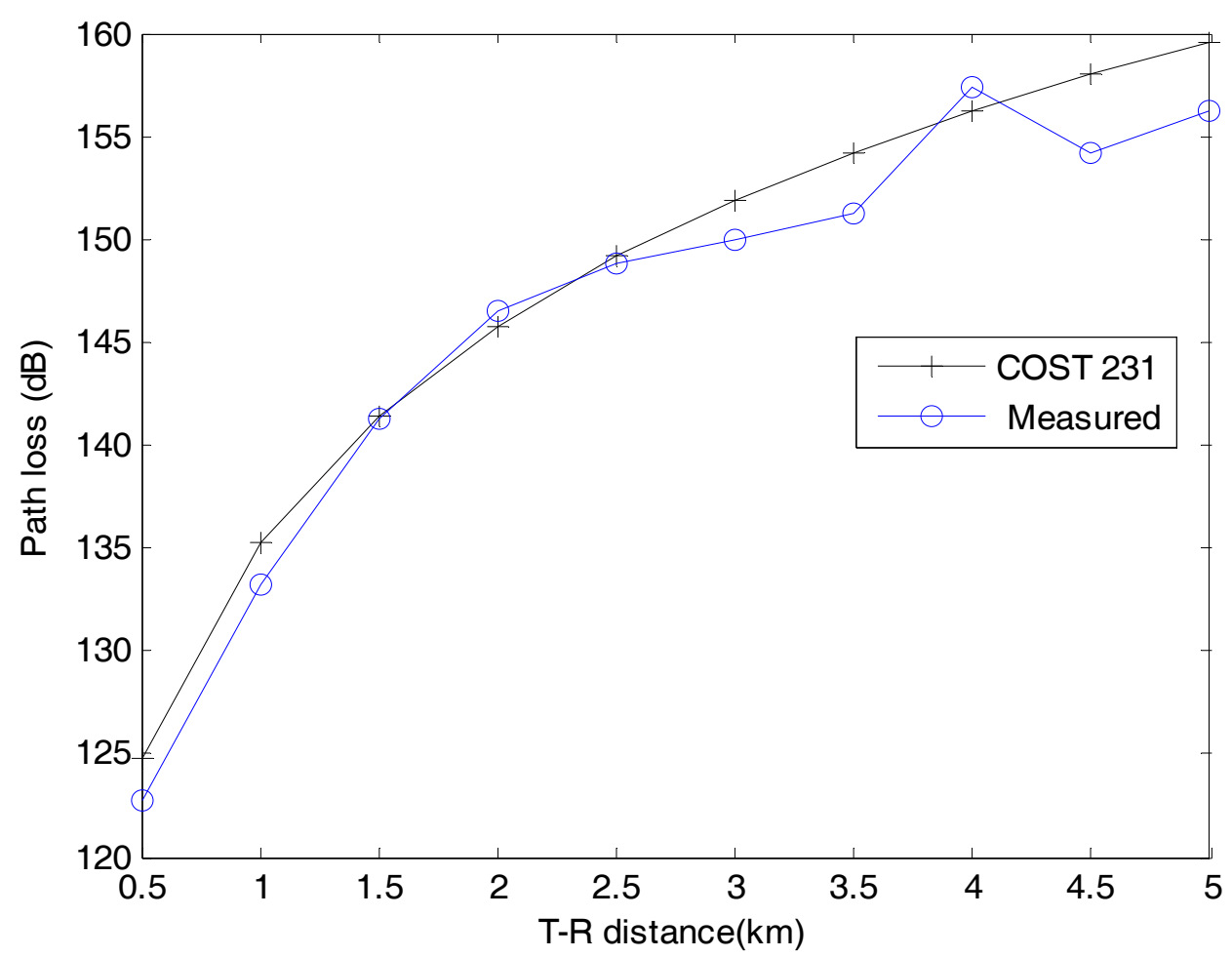

Figure 2b. Path loss at $1800 \mathrm{MHz}$ for COST231 model and measured for Ogui Rd 


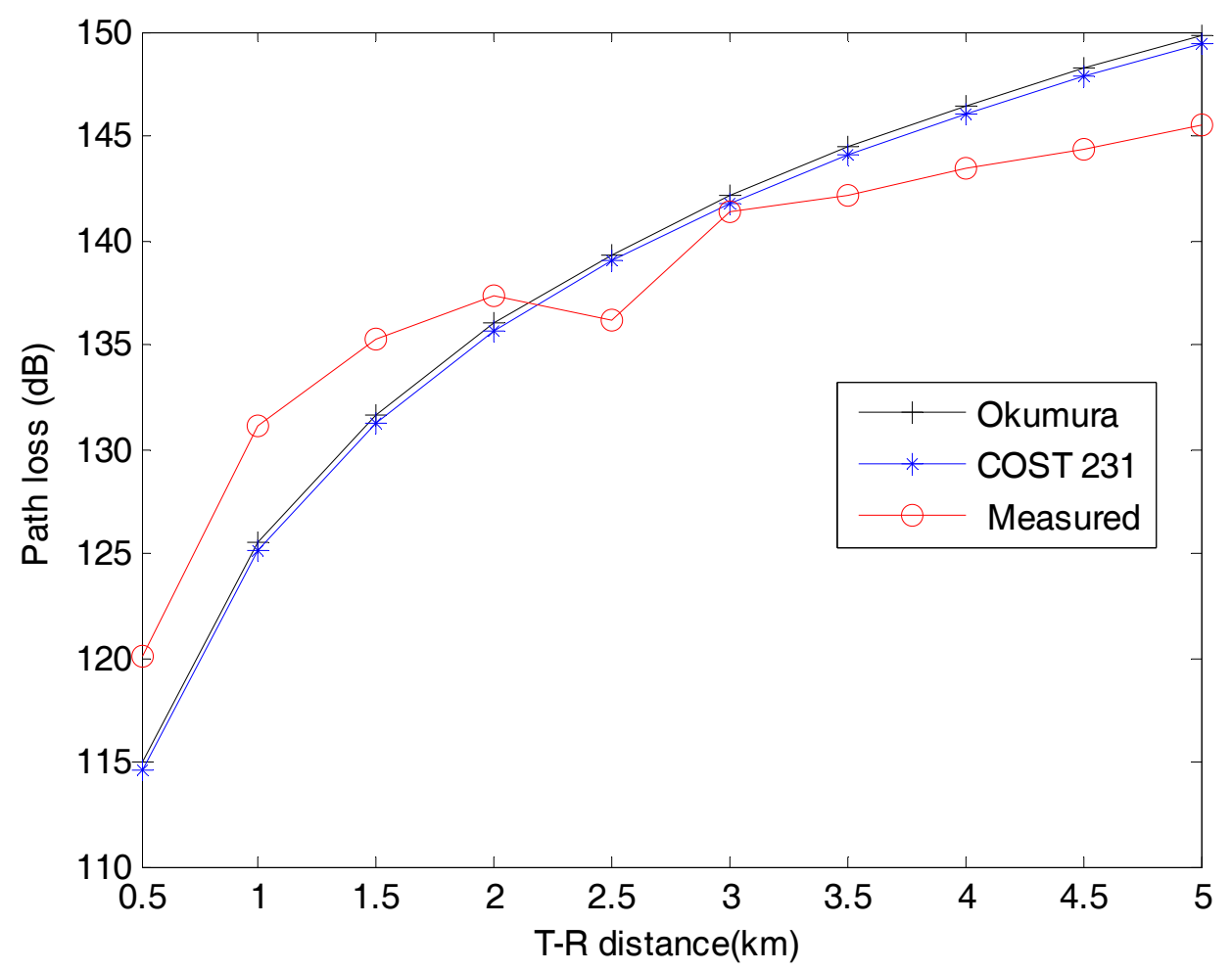

Figure 3a. Path loss at $900 \mathrm{MHz}$ for classic models and measured for Mile One

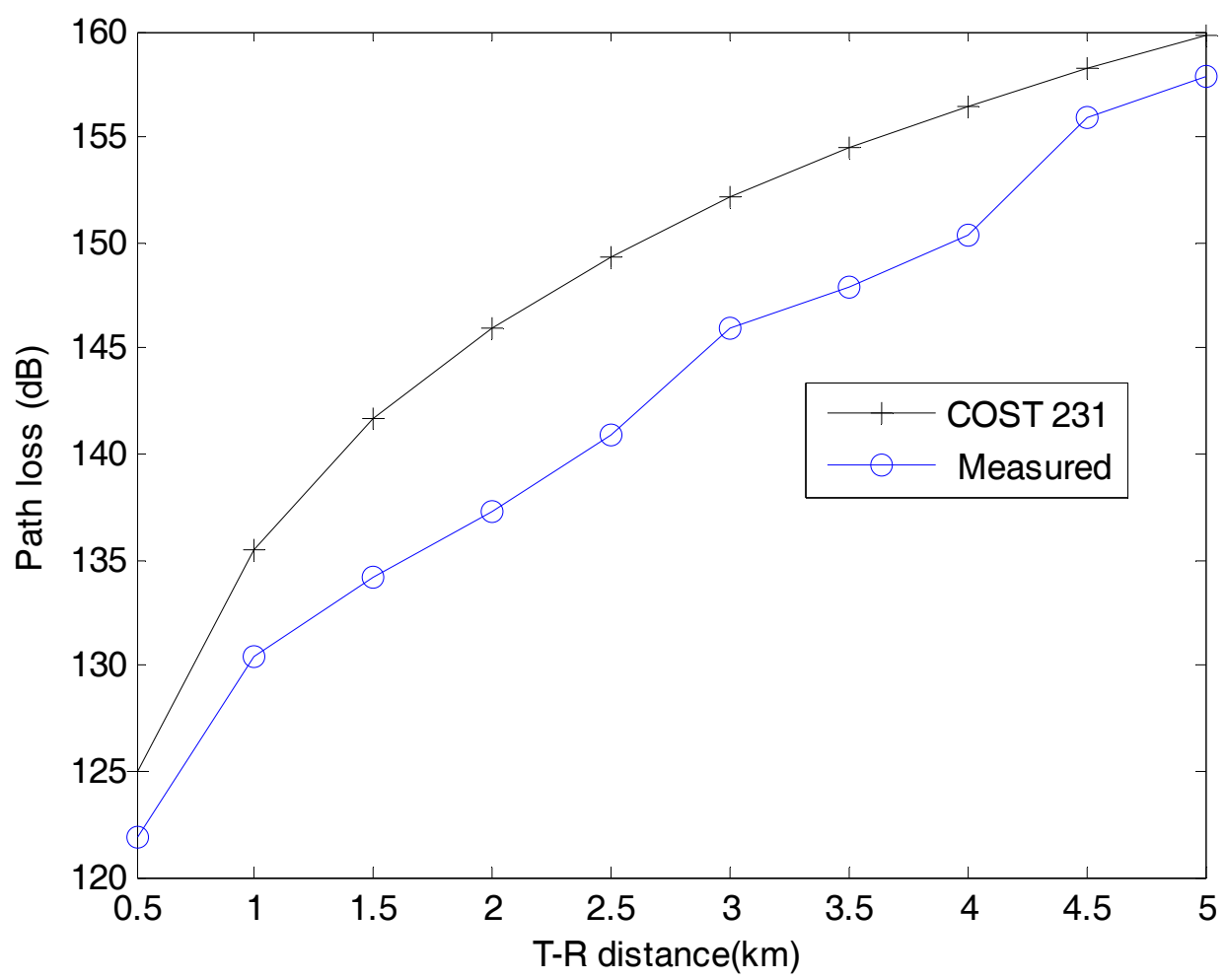

Figure 3b. Path loss at $1800 \mathrm{MHz}$ for COST231 and measured for Mile One 


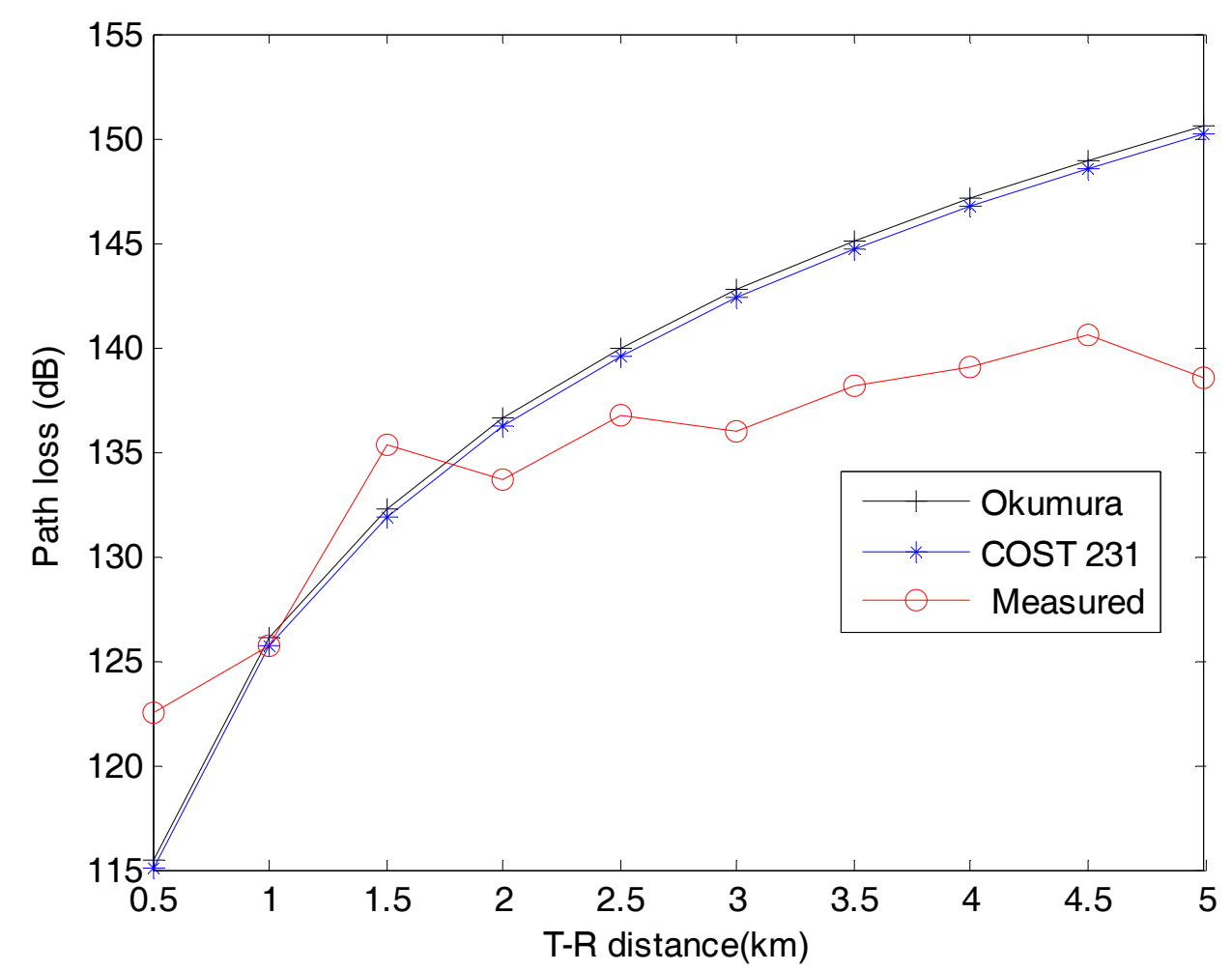

Figure 4a. Path loss at $900 \mathrm{MHz}$ for classics and measured for Rumuolumeni

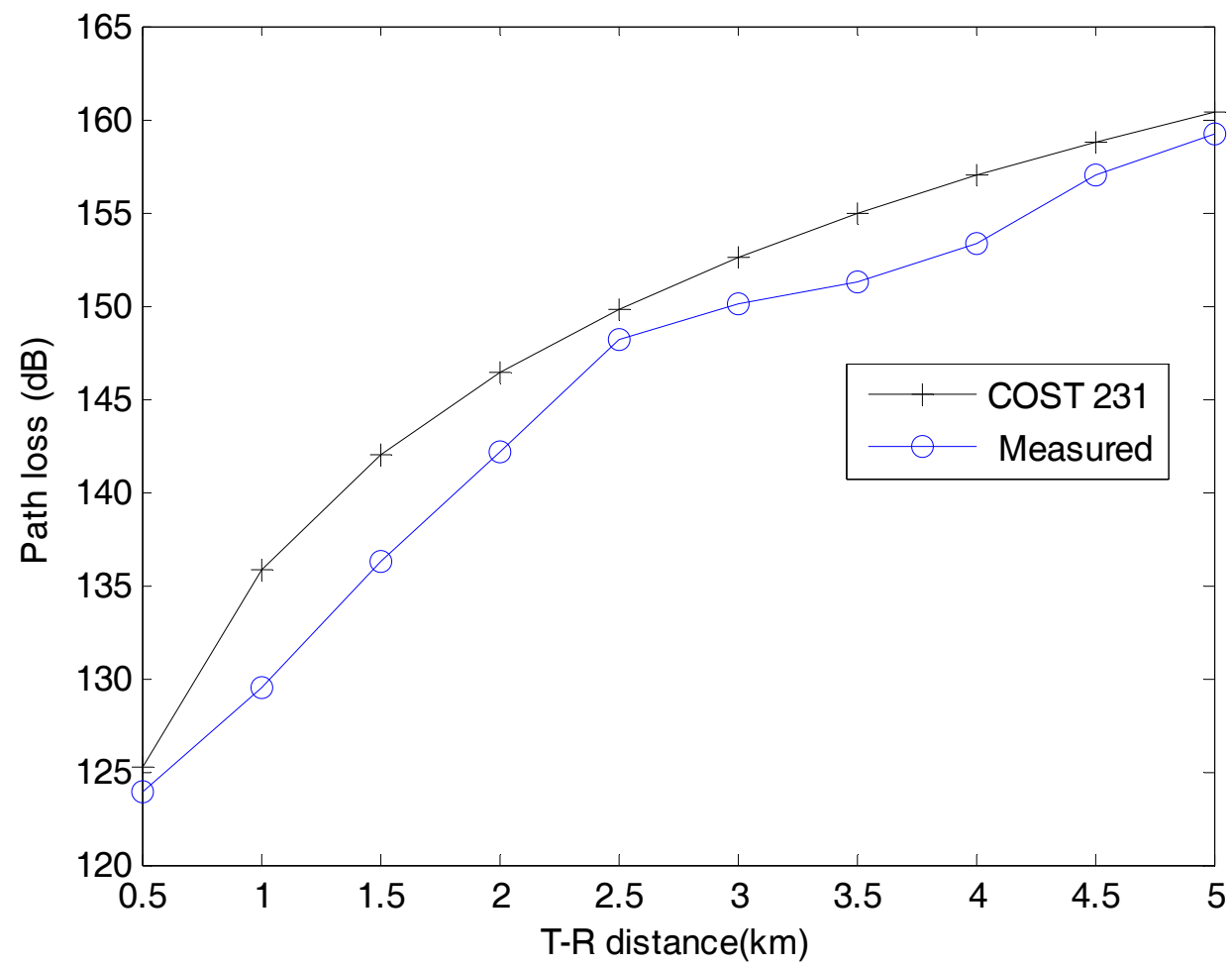

Figure 4b. Path loss at $1800 \mathrm{MHz}$ for COST231 and measured for Rumuolumeni 


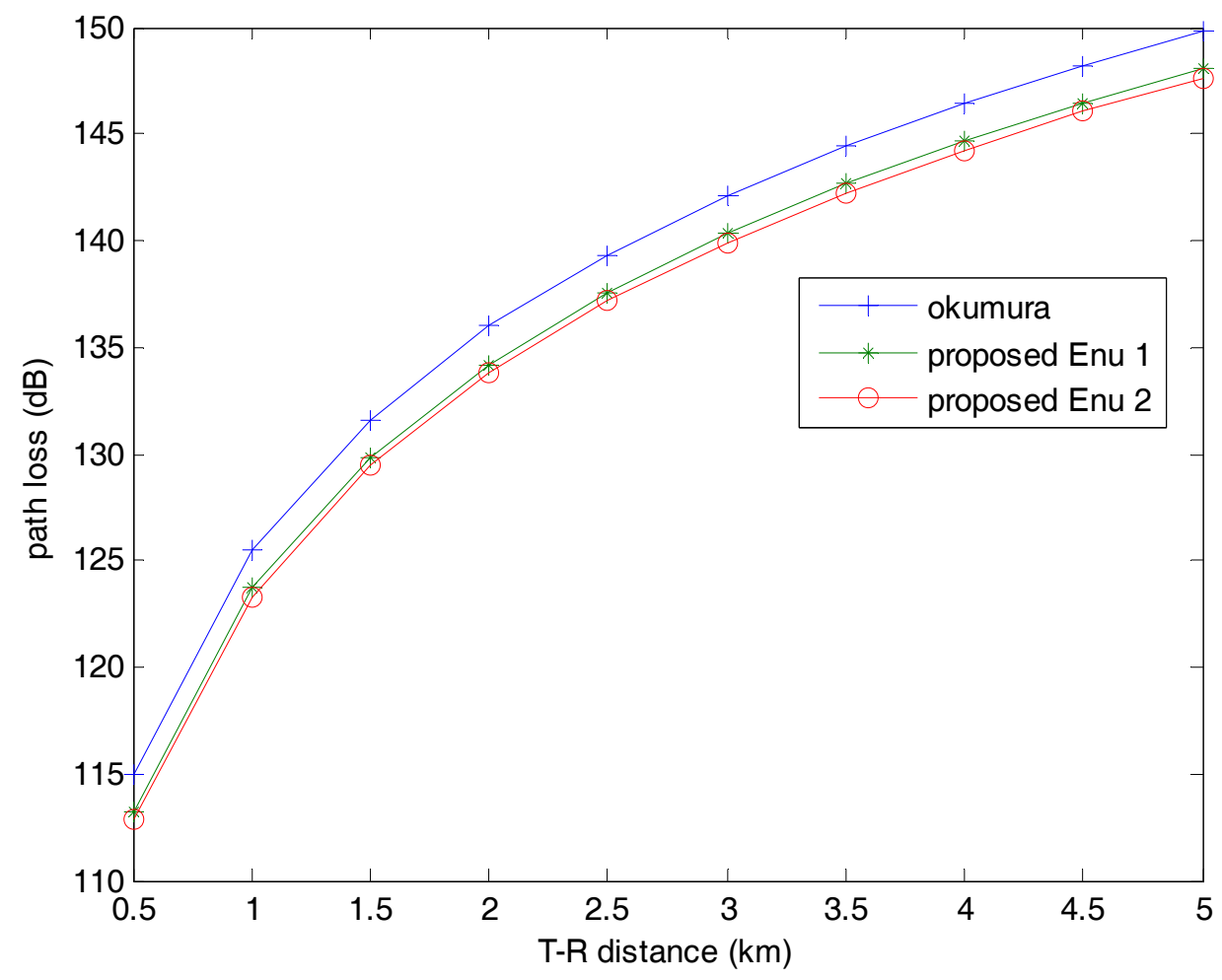

Figure 5. Path loss at $900 \mathrm{MHz}$ for classic models and proposed for Enugu

Table 1. Standard deviations $(\sigma)$ and mean square errors $\left(\mu_{\mathrm{e}}\right)$ of the Okumura and COST 231 models at 900 $\mathrm{MHz}$ for these routes

\begin{tabular}{llllll}
\hline City & Location & \multicolumn{2}{l}{ Okumura (dB) } & \multicolumn{2}{l}{ COST (dB) } \\
\hline \multirow{2}{*}{ Enugu } & Agbani Road & 1.77 & 5.58 & 1.42 & 4.50 \\
& Ogui Road & 2.21 & 6.99 & 1.86 & 5.88 \\
\multirow{3}{*}{ Port Harcourt } & Mile One & 0.8 & 2.71 & 0.60 & 1.91 \\
& Rumuolumeni & 5.04 & 15.94 & 4.76 & 15.04 \\
\hline
\end{tabular}

Table 2. Standard deviations and mean square errors for COST 231 at $1800 \mathrm{MHz}$

\begin{tabular}{llll}
\hline \multirow{2}{*}{ City } & \multirow{2}{*}{ Location } & \multicolumn{2}{c}{ COST (dB) } \\
\cline { 3 - 4 } Enugu & Agbani Road & 0.11 & 0.36 \\
& Ogui Road & 1.50 & 4.75 \\
\multirow{3}{*}{ Port Harcourt } & Mile One & 5.40 & 17.07 \\
& Rumuolumeni & 2.78 & 8.78 \\
\hline
\end{tabular}

Table 3. Proposed modified equations for both Okumura-Hata and COST 231 at $900 \mathrm{MHz}$ for the cities

\begin{tabular}{|c|c|c|c|}
\hline City & Location & Okumura-Hata Equations $\left(P_{L}=\right)$ & COST Equations $\left(P_{L}=\right)$ \\
\hline \multirow{2}{*}{ Enugu } & Agbani Road & $124.69+34.79 \log _{10}(\mathrm{~d})$ & $124.63+34.79 \log _{10}(\mathrm{~d})$ \\
\hline & Ogui Road & $123.30+34.79 \log _{10}(\mathrm{~d})$ & $123.28+34.79 \log _{10}(\mathrm{~d})$ \\
\hline \multirow{2}{*}{ Port Harcourt } & Mile One & $123.80+34.79 \log _{10}(\mathrm{~d})$ & $123.64+34.79 \log _{10}(\mathrm{~d})$ \\
\hline & Rumuolumeni & $120.87+35.04 \log _{10}(\mathrm{~d})$ & $120.94+35.04 \log _{10}(d)$ \\
\hline
\end{tabular}


Table 4. Proposed modified COST231 equations at $1800 \mathrm{MHz}$ for the cities

\begin{tabular}{lll}
\hline City & Location & COST Equations $\left(\mathbf{P}_{\mathbf{L}}=\right)$ \\
\hline \multirow{2}{*}{ Enugu } & Agbani Road & $135.20+34.78 \log _{10}(\mathrm{~d})$ \\
& Ogui Road & $133.80+34.78 \log _{10}(\mathrm{~d})$ \\
\multirow{2}{*}{ Port Harcourt } & Mile One & $130.00+34.79 \log _{10}(\mathrm{~d})$ \\
& Rumuolumeni & $132.70+34.86 \log _{10}(\mathrm{~d})$ \\
\hline
\end{tabular}

The two routes considered in cityof Enugu were from Agbani Road to Ogbete market and from Ogbete market to Ogui Road. Along Agbani Road the BTS was located very close to 103 motorised Battalion of the Nigerian army. The test drive started from there to Zik Avenue and terminated close to the market. The path loss values along these routes were very high giving a standard deviation of $2.55 \mathrm{~dB}$ and $6.99 \mathrm{~dB}$ for Okumura, $1.6 \mathrm{~dB}$ and $5.88 \mathrm{~dB}$ for COST 231 model at $900 \mathrm{MHz}$. At $1800 \mathrm{MHz}$, the mean square error had values of $0.11 \mathrm{db}$ and 1.5 $\mathrm{db}$. The path loss values exceeded the classic values in most cases. This was because of the undulating nature of the routes. The BTSs were sited on top of hills and this led to very high values of path loss along the depressions on the routes.

It is well known that every physical entity that a radio signal encounters after it leaves the antenna affects the strength and direction of the signal. This is very evident from the readings obtained along these routes in the rainy season.

Ikwerre Road in Mile One was the area for the first sets of drive test in the city of Port Harcourt. This is a very busy area of the city and the drive test started from Mile One Market along Ikwerre Road towards the NEPA office. This area is highly unplanned accounting for the very high path loss values of $138.47 \mathrm{~dB}$ and $142 \mathrm{~dB}$ as the average at $900 \mathrm{MHz}$ and $1800 \mathrm{MHz}$ respectively. The rainy season was in full swing as at the time of the readings. This definitely contributed.

The second route in the city started from Whimpie Junction to Iwofe Road and then to Aker Road. This area is more open than Ikwerre Road and therefore the values were lower (135.01 dB at $900 \mathrm{MHz})$.

Even though the mean square errors were quite small, due to inadequate base stations, the quality of service and coverage are still poor due to poor planning and very large cells.

\section{Conclusion}

Planning and cell dimensioning should always be in advance of traffic demand. These variables are dependent on reliable growth and prediction of future traffic trend. The overall network plan must ensure appropriate design, implementation and maintenance of the entire segments of the network. With these segments having appropriate circuit equivalents, the assurance of quality can be guaranteed.

The measurements were taken during the rainy season and hence thicker foliage contributing to the high values in some areas. The proposed modified Okumura Hata and COST 231Hata models could be fully adapted for these cities because amongst other considerations, they make provision for rain attenuations as well as the unique features of these cities.

\section{References}

Abhayawardhana, V. S., Wassel, I. J., \& Crosby, D. (2003). Comparison of empirical propagation path loss models for fixed wireless access system. 61 th IEEE Vehicular Tech. Conference, Stockholm, Sweden, May.

Cavalcante, G. P. S., Rogers, D. A., \&Giarola, A. J. (1983). Radio loss in forest using a model with four layered media. Radio Service, 18, 5-10.

COST Action 231. (1999). Digital mobile radio towards future generation systems, final report. Tech. Rep. European Committees, EUR 18957.

Crane, R. K. (1980). Prediction of attenuation by Rain. IEEE Trans. on Communication, COM-28, 1727-1732.

Georgiadou, E. M., Panagopoulous, A. D., \&Kanellopoulous, J. D. (2006). Millimetre wave pulse propagation through distorted rain drops for loss fixed wireless access channels. Journal of Electromagnetic Waves and Appl., 20(9), 1235-1248. http://dx.doi.org/10.1163/156939306777442953

Hata, M. (1981). Empirical for propagation loss in land mobile radio services. IEEE Transaction on Vehicular Technology, VT- 29, 317-325. http://dx.doi.org/10.1109/T-VT.1980.23859 
Medeisis, A., \& Kajackas, A. (2000). On the use of the Universal Okumura-Hata Propagation Prediction Model in Rural Areas. Vehicular Technology Conference Proceedings, VTC Tokyo, 3, 1815-1818.

Nadir, Z., Elfadhil, N., \&Touati, F. (2008). Path loss using Okumura-Hata model and spline interpolation for missing data for Oman. Proceeding of world congress on engineering 2008, vol. 2 WCE, July 2-4, London, UK.

Okumura, Y., Ohmori, E., \& Kawano, T. (1968). Fixed strength and it's variability on VHF and UHF land mobile radio-services. Review of the Electrical Communication Laboratory, vol. 16 September-October.

Parson, J. D. (2000). The mobile radio propagation channel (pp. 52, 193, 380-381). New York: Willey and Sons Inc. http://dx.doi.org/10.1002/0470841524

Rappaport, T. S. (2003). Wireless communication-principles and practise. Prentice Hall, India, New Delhi.

Saunders, S. R., \& Hata, M. (1980). Empirical formula for propagation loss in Land mobile radio services. IEEE Transactions on Vehicular Technology, VT29, August.

Tamir, T. (1977). Radio propagation along mixed paths in forest environments. IEEE transactions on antennas and propagation, AP-25(4), 471-477. http://dx.doi.org/10.1109/TAP.1977.1141620

Wilson, R. D., \& Scholtz, R. A. (2003). Comparison of CDMA and modulation schemes for UWB radio in a multipath environment. Proceedings of IEEE global telecommunication conference, 2, Dec.

\section{Copyrights}

Copyright for this article is retained by the author(s), with first publication rights granted to the journal.

This is an open-access article distributed under the terms and conditions of the Creative Commons Attribution license (http://creativecommons.org/licenses/by/3.0/). 